\title{
Heidi Grönstrand
}

\section{Kaksi maata, kaksi kulttuuria Sofi Oksanen suomalaisen kirjallisuuden kartalla}

Monikulttuurisuus ja monikulttuurisuudesta keskusteleminen on rantautunut osaksi suomalaista arkipäivää ja akateemista maailmaa. 'Monikulttuurisuus'-käsitteen käyttöä kritisoidaan muun muassa siitä, että sitä viljellään aina tarpeen tullen poliittisessa puheessa sen kummemmin sisältöjä miettimättä ja käytetään kuvaamaan jonkinlaista ihanteellisen yhteiskunnan tilaa, johon tulee yhteiskuntapoliittisin keinoin pyrkiä (esim. Huttunen et al. 2005, 20-21; Martikainen et al. 2006, 14). Samaan aikaa se on myös käsite, jota tarvitaan. Sen avulla voidaan mitä ilmeisimmin jäsentää suomalaista yhteiskuntaa koskevia muutoksia - sellaisia ilmiöitä, jotka maahanmuutto ja uudenlaiset ryhmät omine erityisine kulttuureineen on tehnyt tutuksi (myös Huttunen et al. 2005,17). ${ }^{1}$

Kirjallisuudentutkijatkin ovat jo pitkään tunteneet tarvetta käsitteellistää sitä, että suomalaista kirjallisuutta kirjoittaa entistä useammin kirjailija, jonka tausta on jossakin muussa maassa ja kulttuurissa kuin Suomessa. Zinaida Lindénin tai Umayya AbuHannan kaltaisista kirjailijoista puhutaan maahanmuuttajakirjailijoina, monikulttuurisina tai kahden kulttuurin kirjailijoina (esim. Rantonen 2006; Nissilä 2007 ja 2009). Mitään sellaista yhteistä nimitystä, joka tekisi oikeutta kirjailijoiden erilaisille taustoille ja lähtökohdille, ei kuitenkaan ole (Nissilä 2009, 50). Ei ole myöskään mitään sellaista yhtä oikeaa tai oikeutettua nimitystä, joka kuvaisi näiden kirjailijoiden teoksia. Puhutaan esimerkiksi monikulttuurisesta kirjallisuudesta, uussuomalaisesta, ylirajaisesta ja diasporisesta kirjallisuudesta, mutta mikään näistä epiteeteistä ei ole kaiken kattava tai edes likimainkaan tyydyttävä. Esimerkiksi Eila Rantonen (2009) esittää, että näissä nimityksissä yhdistyvät aiemmat siirtolais- ja pakolaiskirjallisuuden käsitteet. Ne nostavat monien kirjailijoiden karvat pystyyn, koska uudissanat haiskahtavat byrokratialta ja politiikalta ja niihin liittyy kielteisiä mielikuvia.

Kuulun itsekin niihin, joita nämä edellä mainitut nimitykset häiritsevät, koska ne tekevät eroa johonkin suomalaiseksi miellettyyn - ja suomalaiseksi tiedettyyn - kirjallisuuteen ja tulevat tuottaneeksi tahattomastikin sellaisia eroja, jotka eivät välttämättä ole perusteltuja. Samaan aikaan ne tosin tekevät näkyväksi sen, että suomalaisuutta ja suomalaista kirjallisuutta on yhä hankalampi määritellä (vrt. myös Gröndahl 2007, 21).

\section{Sofi Oksanen suomalaisen kirjallisuuden haastajana}

Sofi Oksanen on kiinnostava esimerkki kirjailijasta, johon ei ole liitetty hänen taustaansa liittyviä määreitä ja jonka suomalaisuutta ei ole kyseenalaistettu. Tähän on aikaisem- 
min kiinnittänyt huomiota Hanna-Leena Nissilä Kulttuurintutkimus-lehdessä 1/2009 ilmestyneessä artikkelissaan:

Mielenkiintoista on, että vuonna 2003 esikoisteoksensa julkaissut, suomalaisen isän ja virolaisen äidin tytär Sofi Oksanen ei juurikaan ole joutunut tällaisen suomalaisuuden ja monikulttuurisuuden märittelyn kohteeksi kirjallisuusinstituution taholta. Hän on päinvastoin viime aikoina itse aktiivisena osapuolena tuonut omaa virolaisuuttaan esille. Monikulttuurisuus näyttääkin näissä arvioissa, kuten usein arkipuheessakin, olevan kiertoilmaisu etniselle ja kulttuuriselle poikkeavuudelle, "eksoottisuudelle" (vrt. Löytty 2004a, 225).

(Nissilä 2009, 43.)

Nissilä analysoi Ranya ElRamlyn palkittua teosta Auringon asema, joka julkaistiin vain vuotta aikaisemmin kuin Sofi Oksasen esikoisteos Stalinin lehmät. Mutta toisin kuin Stalinin lehmiä, Auringon asemaa luonnehdittiin monikulttuuriseksi ja jälkikoloniaaliksi romaaniksi. Se luokiteltiin maahanmuuttajakirjallisuudeksi, vaikka samalla todettiin, ettei ElRamly ole maahanmuuttaja. Lisäksi kirjailija itse sai "eksoottisen" ja "ulkomaalaisen" roolin ja joutui toistuvasti vakuuttelemaan suomalaisuuttaan. (Nissilä 2009, 50.)

Sofi Oksaselle ei siis ole annettu eksoottisen ja ulkomaalaisen roolia, vaikka lehtihaastatteluissa ja muissa kirjoituksissa Oksanen ei ole peitellyt taustaansa. Aivan tuoreena esimerkkinä on Teos- ja Söderströms -kustantamojen yhteistyönä syntynyt kirja $\mathrm{Me}$ muut. Kirjoituksia yhteiskuntaluokasta (2009), jossa Sofi Oksanen yhtenä kirjoittajana pohtii omiin kokemuksiinsa pohjaten luokkakysymyksiä ja vertailee Viroa ja Suomea keskenään.

Paitsi oman taustansa varsinkin käsittelemiensä aiheiden perusteella Oksanen olisi luettavissa niiden kirjailijoiden joukkoon, joiden tuotannossa kaksi maata, kaksi kulttuuria ja kaksi kieltä ovat läsnä. Ennen kaikkea Stalinin lehmät on romaani, jossa suomalaisuus ja virolaisuus - tai näiden kahden kulttuurin välisyys - ovat keskiössä. Monet suomalaiset kriitikot tosin lukivat teosta pitkälti syömishäiriöromaanina. Monien mielestä myös Viroa ja Viron historiaa koskevia asioita oli romaanissa aivan liikaa.

Itseäni Stalinin lehmissä on nimenomaan kiinnostanut kuvaus kulttuurien moninaisuudesta ja sekoittumisesta. Toisaalta ei tarvitse pysytellä pelkästään kulttuurin tai kulttuurierojen akselilla; tärkeänä teoksen halki kulkevana juonteena on vaikeneminen ja salaaminen, mikä antaa myös mahdollisuuden laajentaa näkökulmaa. Kaikilla ihmisillä lienee luurankoja kaapissaan, jotain, mistä he mieluiten vaikenisivat leimautumisen ja häpeän pelossa. Teos käsittelee asioita, jotka koskettavat kaikkia ihmisiä, riippumatta siitä, elääkö omassa vai vieraassa maassa, yhdessä vai kahdessa kulttuurissa - tai kulttuurien välissä. Vaikenemisen teemaan viittaa kirjailija itsekin Suomen Kuvalehden haastattelussa vuonna 2007: "Oikeastaan Stalinin lehmissä on kyse vaikenemisen vaikutuksista [--]. Siksi menneisyyden penkominen ja vaikenemisen murtaminen on niin tärkeää." (Järvinen 2007.) 


\section{Kieli ja stigmatisoinnin pelko}

Stalinin lehmissä päähenkilö-kertoja Annan taustasta, hänen virolaisista juuristaan, tulee salaisuus ja vaikenemisen aihe. Annan äiti Katariina kieltää tytärtään kertomasta, mistä äiti on kotoisin. Hän ei myöskään puhu tyttärelleen viroa, ei edes vahingossa. Hän salaa virolaisuutensa, ja tytär joutuu tekemään samoin. Annan ja hänen äitinsä olemassaolo ja identiteetti alkavat rakentua yhtäältä vaikenemiselle, toisaalta pyrkimykselle ja jatkuvalle uurastukselle olla oikea, normaali ja hyväksyttävä suomalainen - minkä osana on luonnollisesti myös suomen kieli. Itse asiassa jo aivan romaanin alussa mainitaan äidin suomen kielen opettelu, ensimmäisten sanojen hahmottaminen, huomion kiinnittäminen suomen ja viron ääntämyksen ja sanaston välisiin eroihin sekä suomiviro-keskustelusanakirjan hankkiminen. Kun Katariina muuttaa Suomeen, hän vihaa viron puhumista. Myöhemmin hän ei myöskään suostu uskomaan, että Anna osaa viroa. Hän kääntää aina virolaiset asiat tyttärelleen suomeksi, ja Anna puolestaan antaa äitinsä pysyä luulossaan teeskennellen täysin yksikielistä suomalaista.

Koska kielellä on ollut ja on edelleen tärkeä asema suomalaisuuden rakentamisessa, tarvitaankin entistä enemmän tutkimusta, jossa kieli nähdään tasavertaisessa asemassa sellaisten tutkimuksen pitkään suosimien käsitteiden, kuten sukupuolen, etnisyyden ja luokan rinnalla ja niihin erottamattomasti yhteen kietoutuneina (myös Gröndahl 2007, 27; Pavlenko 2005, 1-5). Stalinin lehmissäkin Katariina-äidin suomen kielen opettelu ja kielen merkityksen korostaminen on investointia hänen tavoittelemaansa identiteettiin (vrt. Pavlenko 2005, 198). Suomenkielisyys on tärkeä osa symbolista pääomaa, niitä uusia mahdollisuuksia, joita hän ajattelee Virosta pois pääsemisen tuovan mukanaan. Ja äiti haluaa myös, että tyttärestäkin tulee täysin suomalainen - sysisuomalainen, kuten Oksasen termi romaanissa kuuluu - sellainen, jossa ei ole jälkiä virolaisuudesta. Anna kertoo:

Äiti päätti puolestani myös sen, ettei minun tarvitse Sysi-Suomessa kasvaneena ja siten muka sydämen syvintä solaa myöten sysisuomalaisena muistaa sitä maata, josta hän on tullut, ei vaikka me kävimmekin siellä, ei, vaikka hän ikävöi takaisin. Eihän niitä matkoja edes ollut olemassa, kun niistä ei puhuttu kenelläkään Suomessa. Minusta piti tulla suomalainen. Piti puhua, kävellä kuin suomalainen, näyttää siltä kuin suomalainen, vaikka olin jatkuvasti poissa paikaltani, jotenkin poissa sijoiltaan, kuin takissa, jonka hihat ovat eripituiset ja liian pienet minulle, kengissä, jotka hankasivat joka askeleella. (S 45.)

Vaikenemista on käsitelty sekä maahanmuuttoa ja etnisiä vähemmistöjä käsittelevässä kaunokirjallisuudessa että sellaisessa tutkimuksessa, joka koskee erilaisia vähemmistöidentiteettejä tai kaksi- ja monikielisyyttä (esim. Thisted 2002; Wendelius 2002; Hansegård 1990; Pavlenko 2005). On puhuttu kielellisestä mykkyydestä tai sisäisestä hiljaisuudesta. Nämä metaforat on liitetty sellaisiin kielellisiin vähemmistöihin, jotka ovat eläneet painostuksen alla, tai maahanmuuttajiin, jotka elävät kahden 
kielen välissä (Wendelius 2002). On käsitelty esimerkiksi ruotsinsuomalaisten tilannetta ja sitä, kuinka maahanmuuttajan leimaaminen, stigmatisointi, konkretisoituu kielessä silloin, kun ihminen ei uskalla puhua omaa kieltään leimautumisen pelossa (Vallenius 2002). Stalinin lehmissä Annakin puhuu noloudesta ja häpeästä. Hän sanoo, että nolous on samassa piilossa kuin virolaisuus. Se on jotain, mitä hän ei edes osaa nimetä. (S 87.)

Kaksikielisyyden tai kahden kulttuurin välissä elämisen yhdistämisellä pelkästään negatiivisiin piirteisiin ja suoranaisella patologisoinnilla on tutkimuksessa (kielitieteessä, psykologiassa, kasvatustieteissä, sosiologiassa ja epäilemättä monissa muissakin tieteissä) pitkät perinteet (ks. esim. Skutnabb-Kangas 1981, 66; Pavlenko 2005, 223-228). Ilmiö on yhdistetty pelon ja vieraantumisen tunteisiin, häpeään ja apatiaan - ylipäätään kaikenlaisiin tunne-elämän kehityksen häiriöihin (Pavlenko 2005, 223-225). Kaksikielisiä ja kahden kulttuurin kasvatteja on pidetty epäilyttävinä kielellisinä ja kulttuurisina hybrideinä, joilla on ristiriitainen suhde itseensä. Heitä on pidetty yksilöinä, joiden vaihtuvat kielelliset uskollisuudet viittaavat vaihtuvaan poliittiseen ja moraaliseen uskollisuuteen. (Pavlenko 2005, 24.) Tosin patologisointi on koskenut ennen kaikkea siirtolaisia, maahanmuuttajia ja kielellisiä tai etnisiä vähemmistöjä. Yläluokan ja keskiluokan kaksikielisyys ja kyky liikkua eri kulttuurien välillä on tyypillisesti esitetty positiivisena ilmiönä. (Skutnabb-Kangas 1981, 68; Pavlenko 2005, 24.)

Yhtenä syynä tämäntyyppisen ajattelun yleistymiseen on ollut muun muassa nationalismin voittokulun myötä yleistynyt yksikielisyyden normi. Kun Euroopassa, Suomi mukaan lukien, tavoiteltiin kansan, kielen, kansakunnan tai valtion yhdistämistä, kielelliset ja etniset vähemmistöt pyrittiin erilaisin kieli- ja koulutuspoliittisin ja muiden toimenpiteiden avulla assimiloimaan valtaväestöön (esim. Lindgren \& Lindgren 2005, 257).

Stigmatisoinnin pelko on epäilemättä yksi tapa selittää Stalinin lehmien vaikenemisen teemaa. Pukeutuminen on yksi esimerkki niistä sukupuolta, kulttuuria ja kansallisuutta koskevista vaatimuksista, joiden osa Anna on ja joista poikkeaminen leimaa hänet väistämättä erilaiseksi ja ei-suomalaiseksi. Anna haluaisi käyttää Suomessa hametta mutta

80-luvulla suomalaisnaiset eivät käytä hameita, eivätkä tytöt koulussa, ja sen vuoksi Annan on naamioiduttava Suomessakin suomalaiseksi pukeutumalla farkkuihin, sulauduttava, vaikka hän ei oikeasti haluaisi. Kerran Anna laittaa kotihameensa tarhaan päälle ja tarhatäti kysyy heti, että onko Annalla syntymäpäivä, kun on niiiin [!] koreat vaatteet." (S 37-38.)

Lisäksi kysymys kielestä liittyy sekin kiinteästi stigmatisoinnin pelkoon ja välttämiseen. Annan äiti selittää sukulaisilleen, että jos Anna puhuu Suomessa vahingossa viroa hiekkalaatikolla, hän leimautuu ryssäksi. Tämä kertoo siitä, että virolaiset olivat suomalaisille pitkään venäläisiä. Tässä mielessä Annan potentiaalinen (tai pikemminkin 
piilossa oleva) kaksi- tai monikielisyys on luonteeltaan erilaista kuin muiden sellaisten kaksikielisten suomalaisten, joiden kieliin ja kulttuureihin ei liity yhtä voimakkaita arvoja ja asenteita.

\section{Monikielisyyden tunnistaminen ja tunnustaminen}

Monikielisyyttä koskeviin aikaisempiin tutkimuksiin on usein sisältynyt usein ajatus jakaantuneesta identiteetistä tai traumoista ja niiden tukahduttamisesta, eikä niissä ole otettu huomioon laajempaa yhteiskuntapoliittista, kulttuurista ja historiallista kontekstia (Pavlenko 2005, 30-31). Stalinin lehmissä varsinkin Annan äidin kohdalla vaikeneminen liittyy myös haluun välttää vainoja ja vaikeuksia - kuulusteluja, neuvostoviranomaisia, KGB:tä. Myös neuvostoviranomaiset odottivat, että maasta lähtevä jättää taakseen kotinsa, kansansa ja kielensä omaa nimeään myöten. Katariinan tapauksessa on siis ainakin jossakin määrin kyse sellaisesta kielen ja kulttuurin vaihdosta, jota motivoivat poliittiset ja ideologiset syyt (vrt. Pavlenko 2005, 201).

Katariina ei investoi vain uuteen kansallisuuteen vaan myös poliittiseen yhteenkuuluvaisuuteen. Hän vastustaa kieltä, joka yhdistyy epäoikeudenmukaisuuteen ja sellaiseen poliittiseen järjestelmään, jonka osa hän ei halua olla. (Vrt. Pavlenko 2005, 221.) Suomessa viehättää vapaus, mutta silti olot ovat paradoksaalisesti monella tapaa kuin Siperiassa. Katariina ikävöi koko ajan kotiin ja Viroon, eikä suomalaiseksi tulemisen prosessi siis ole millään tavalla helppo. Kohtalon ivaa onkin, että sinä hetkenä, jolloin paluu vanhaan kotimaahan olisi mahdollinen, sekä äiti että tytär tuntevat itsensä suomalaisiksi tai ainakin enemmän suomalaisiksi kuin virolaisiksi. Tätäkin seikkaa voi pitää paradoksina tai traumaattisena kokemuksena ainakin silloin, kun mittatikkuna on yksikielisyys ja -kulttuurisuus. Jos taas lähtökohtana on ajatus monikielisyydestä ja monikulttuurisuudesta normaalina ilmiönä, huomaa sen, mitä useat monikielisyystutkijat nykyisin sanovat: kielten välinen suhde ei ole koskaan staattinen, ja eri elämäntilanteissa kielillä ja kulttuureilla voi olla erilainen painoarvo (esim. Kellman 2000; Lehtonen 2008).

Kun seurataan Stalinin lehmien Anna-tyttären tarinaa loppuun saakka, saadaan tietää, että traumasta ja vaikenemisen pakon aiheuttamista ongelmista on mahdollisuus myös toipua. Annan saadessa kertoa elämästään, juuristaan ja Virosta, syömishäiriö alkaa osoittaa tasaantumisen ja hellittämisen merkkejä. Kahdessa maassa, kahdessa kulttuurissa ja kahdessa kielessä eläminen ei kenties sittenkään jätä pysyviä vaurioita.

\section{Puhdistus - suomalaisen kirjallisuuden ytimessä?}

Siinä missä Stalinin lehmät aukeaa melko helposti sellaiselle luennalle, jossa huomio on kulttuurien ja kielten välisyydessä ja kaksi- ja monikulttuurisuuden problematisoinnissa - tai mitä nimitystä sitten halutaankaan käyttää - Puhdistus on jo aivan toinen 
juttu. Hyvällä syyllä voi kysyä, miten Puhdistus suhtautuu edellä kuvattuun asetelmaan.

Vaikka Puhdistuksessa liikutaan kokonaan virolaisessa kontekstissa, ei voida kuitenkaan ohittaa sitä tosiasiaa, että virolaista historiaa kuvaa nimenomaan suomalainen kirjailija tai että suomalaisten palkitsema ja lukema romaani kuvaa nimenomaan virolaista historiaa. Kaksi kulttuuria ja kaksi kieltä ovat tässäkin teoksessa läsnä siitä huolimatta, että se on suomeksi kirjoitettu romaani virolaisten historiasta ja lähimenneisyydestä. Vaikka suomalaiselle historialliselle romaanille ja varsinkin sellaisille romaaneille, jotka kuvaavat toisen maailmansodan aikaisia tapahtumia on perinteisesti asetettu erityisiä vaatimuksia uskottavuuden suhteen, Puhdistuksen historianäkemystä ja uskottavuutta ei ole kyseenalaistettu. Sitä on luettu realistisena ja totena kuvauksena, suoranaisena historiankirjoituksena, virolaisten elämästä neuvostomiehityksen alla ja laajemmin kaikkia länsimaita koskettavana toisen maailmansodan aikaisista vieläkin vaietuista tapahtumista.

Sofi Oksasen kykyä ja kompetenssia kuvata tapahtumia ei ole kyseenalaistettu edes minkään yksityiskohdan osalta, mikä on suorastaan hämmästyttävää, kun otetaan huomioon, mitä monet Suomen talvi- tai jatkosotaa koskevat kuvaukset ovat saaneet osakseen. En usko, että tällainen vakuuttavuus olisi mahdollinen ilman vankkaa viron kielen ja kulttuurin tuntemusta. Oksanen hyödyntää monen muun asian ohella paitsi suomalaista historiallisen romaanin perinnettä myös ennen kaikkea virolaista suullista traditiota.

Puhdistuksen myötä Sofi Oksaselle on annettu paikka suomalaisen kirjallisuuden eturivissä, ja ainakin itse haluan nähdä Oksasen menestyksen merkkinä siitä, että monikulttuurisuus, kaksikulttuurisuus, kulttuurien välisyys ja -ylisyys syistä riippumatta voivat olla luonnollinen osa suomalaista kirjallisuutta ja suomalaisuutta. Mutta koska Sofi Oksasen kohdalla näitä kysymyksiä ei oikeastaan ole käsitelty, herää kysymys, ovatko kulttuurierot merkitseviä ainoastaan silloin, kun niitä voidaan käyttää suomalaisuuden ja sen puhtaan ytimen rajaamiseen? Onko niin, että suomalaisen kirjallisuuden eturiviin ei voi sovittaa kansallisuusrajat ylittävää, kaksikulttuurista tai kaksikielistä kirjailijaa? Onko kyseessä yksinkertaisesti asia, jota ei sovi merkityksellistää?

Mitään yksiselitteistä tai varmaa vastausta näihin kysymyksiin en uskalla antaa. Varmaa lienee vain se, että tutkijoilla, kriitikoilla ja muilla kirjallisuuden kentän toimijoilla pitäisi olla nykyistä enemmän rohkeutta käsitellä niitä kirjallisuuden ilmiöitä, jotka kumpuavat monikulttuurisuuden kaltaisista menneisyyden solmukohdista ja nykypäivän haasteista.

\section{Suomalaiset kahden maan ja kahden kulttuurin kirjailijat}

Tarve puhua monikulttuurisuudesta viittaa osaltaan ajatukseen, että nyt olisi tapahtunut yhtäkkinen muutos, että Suomi olisi yhtäkkiä muuttunut monikulttuuriseksi ja että 
maamme ennen olisi ollut yksikulttuurinen (myös Huttunen et al. 2005, 22), mikä ei tietenkään pidä paikkansa. Kyse on pikemminkin siitä, että homogeenisen suomalaisuuden rakentaminen on ollut poliittinen konstruktio, jossa erilaisuutta on pyritty järjestelmällisesti minimoimaan (Ronkainen 2006, 245). Suomi ei ole aikaisemminkaan ollut sellainen sulkeutunut yhtenäiskulttuuri kuin nationalisesti värittynyt tulkinta menneisyydestä on antanut ymmärtää (Huttunen et al. 2005, 10). Monet ihmiset on kasvatettu ja kasvatetaan edelleen kahdella tai useammalla kielellä, ja maahanmuuttoa on sitäkin erilaista (niin työ, taiteellisen vapauden kaipuu kuin avioliitto ovat aina liikuttaneet ihmisiä maasta toiseen ja tekevät sitä edelleen). On kirjailijoita, jotka kirjoittavat kahdella kielellä tai aivan muulla kuin äidinkielellään. Jotkut puolestaan elävät kahdessa maassa tai Sofi Oksasen tavoin kahdessa kulttuurissa mutta kirjoittavat yhdellä kielellä.

Aino Kallaksesta, Hella Wuolijoesta ja Pentti Saarikoskesta lähtien suomalaisiksi kirjailijoiksi on luettu kahdessa tai useammassa maassa ja kulttuurissa eläneitä kirjailijoita, mutta silti tätä tosiasiaa on liian harvoin tutkimuksessa varsinaisesti problematisoitu. Ainakaan näiden mainittujen kirjailijoiden kohdalla tilanne ei ole antanut aihetta mihinkään erityisiin nimikkeisiin tai epiteetteihin. Jos tätä seikkaa ei 2000-luvulla edelleenkään käsitellä, tullaan väistämättä sitoutuneeksi nationalistisiin, kolonialisoiviin yksikielisyyden ja -kulttuurisuuden ihanteisiin sekä samalla jatkaneeksi vuosikymmeniä kestänyttä tapaa häivyttää suomalaisten väliset kulttuurierot, tehdä ne näkymättömiksi.

Kirjoitus perustuu Helsingin yliopistossa Monikulttuurisuus ja historia virolaisessa kirjallisuudessa -seminaarissa 20.11.2009 pidettyyn esitelmä̈n.

\section{Viitteet}

${ }^{1}$ Monikulttuurisuus-käsitteen käyttöä arvostelevat tutkijat viittaavat muun muassa siihen, että monikulttuurisuudeksi ymmärretään usein monien kulttuuriltaan toisistaan poikkeavien ryhmien samanaikainen olemassaolo ja rinnakkaiselo. Ryhmät nähdään siis selkeästi toisistaan erottuvina yksikköinä, ja rajat piirtyvät liian selkeiksi eikä sosiaalisen vuorovaikutuksen monimutkaisuutta oteta huomioon. (Huttunen, Löytty \& Rastas 2005, 20; Martikainen, Sintonen \& Pitkänen 2006, 14.) 


\section{Lähteet}

S= OKSANEN, SOFI 2003: Stalinin lehmät. Helsinki: WSOY.

GRÖNDAHL, SATU 2007: Identity Politics and Construction of 'Minor' Literatures. Multicultural Swedish Literature at the Turn of the Millenium. - Multiethnica nr 30/2007, 21-29.

HANSEGÅRD, NILS-ERIK I990: Norrbottenfinska språkfrågan. En återblick på halvspråkighetsdebatten. Uppsala: Uppsala universitet, Centrum för multietnisk forskning.

HUTTUNEN, LAURA \& LÖYTTY, OLLI \& RASTAS, ANNA 2005: Suomalainen monikulttuurisuus. Paikallisia ja ylirajaisia suhteita. Teoksessa Suomalainen vieraskirja. Kuinka käsitellä monikulttuurisuutta. Toim. Anna Rastas \& Laura Huttunen \& Olli Löytty. Tampere: Vastapaino. 16-40.

JÄRVInen, elina 2007: Hän. Sofi Oksanen. - Suomen Kuvalehti 10/2007, 60-65.

Kellman, steven G. 2000: The Translingual Imagination. Lincoln \& London: University of Nebraska Press.

kongslien, ingeborg 2007: New Voices, New Themes, New Perspectives: Contemporary Scandinavian Multicultural Literature. - Scandinavian Studies 2/2007, 197-221.

LINDGREN, KLAUS \& LINDGREN, ANNA-RIITTA 2005: Språkbyten bland ståndspersonerna i storfurstendömet i Finland. Teoksessa Svenskt i Finland - Finskt i Sverige 1. Dialog och särart. Människor, sambällen och idéer från Gustav Vasa till nutid. Toim. Gabriel Bladh \& Christer Kuvaja. Helsingfors: Svenska litteratursällskapet. 256-319.

LEHTONEN, Heini 2008: Maahanmuuttajataustaisten koululaisten monet kielet. Teoksessa Nuoret kielikuvassa. Kouluikäisten kieli 2000-luvulla. Toim. Sara Routarinne \& Tuula Uusi-Hallila. Helsinki: SKS. 103-124.

MARTIKAINEN, TUOMAS \& SINTONEN, TEPPO \& PITKÄNEN, PIRKKO 2006: Ylirajainen liikkuvuus ja etniset vähemmistöt. Teoksessa Ylirajainen kulttuuri. Etnisyys Suomessa 2000-luvulla. Toim. Tuomas Martikainen. Helsinki: SKS. 9-41.

NISSILÄ, HANNA-LEENA 2007: Jälkikoloniaalinen naiskirjoitus - Suomalaisen kirjallisuuden uudet tulokkaat. Teoksessa Kolonialismin jäljet. Keskustat, periferiat ja Suomi. Toim. Joel Kuortti \& Mikko Lehtonen \& Olli Löytty. Helsinki: Gaudeamus \& Helsinki University Press. 209-226.

Nissilë, hanna-LeEna 2009: Ranya ElRamly ja Auringon aseman vastaanotto. Kulttuurintutkimus 26:1, 39-53.

pavlenko, anita 2005/2007: Emotions and Multilingualism. Cambridge etc.: Cambridge University Press. 
RANTONEN, EILA 2006: Kirjallisia tuliaisia: maahanmuuttajakirjallisuus kulttuurien välissä. Teoksessa Fiktiota! Levottomat genret ja kirjaston arki. Toim. Kaisa Hypén. Helsinki: BTJ Kirjastopalvelu. 121-135.

RANTONEN, EILA 2009: Muuttavatko maahanmuuttajat suomalaisen kirjallisuuden? Kiiltomato.net (6.11.2009). http://www.kiiltomato.net/?cat=editorial (23.11.2009). RONKAINEN, JUSSI 2006: Monikansalaisuus ja monimuotoistuva suomalaisuus. Teoksessa Ylirajainen kulttuuri. Etnisyys Suomessa 2000-luvulla. Toim. Tuomas Martikainen. Helsinki: SKS. 237-256.

SKUTNABb-KANGAS, TOVE I98 I: Bilingualism or Not: the Education of Minorities. Käänt. Lars Malmberg \& David Crane. Clevedon: Multilingual Matters LTD.

THISTED, KIRSTEN 2002: Som spæk og vand? Om forholdet mellem Danmark og Grønland set fra den grønlandske litteraturs synsvinkel. Teoksessa Litteraturens gränsland. Invandrar-och minoritetslitteratur i nordiskt perspektiv. Toim. Satu Gröndahl. Uppsala: Uppsala universitet, Centrum för multietnisk forskning. 201-240.

VALLENIUS, ERKKI 2002: Finska invandrares ångest och skam i skönlitterär gestaltning. Teoksessa Litteraturens gränsland. Invandrar-och minoritetslitteratur i nordiskt perspektiv. Toim. Satu Gröndahl. Uppsala: Uppsala universitet, Centrum för multietnisk forskning. 231-240.

WENDELIUS, LARS 2002: Den dubbla identiteten. Immigrant-och minoritetslitteratur på svenska 1970-2000. Uppsala: Uppsala universitet, Centrum för multietnisk forskning. 